\title{
THE REDIAL AND CERCARIAL PRODUCTION OF A DIGENEAN IN THE SNAIL HOST IS LOWER WHEN NO CERCARIAL SHEDDING OCCURS
}

\author{
DREYFUSS G.*, VIGNOLES P.* \& RONDELAUD D.*
}

\section{Summary:}

Single- and double-miracidium exposures of Galba truncatula with Fasciola hepatica (two groups) or with Paramphistomum daubneyi (two groups) were carried out under laboratory conditions to compare parasite production in cercaria-shedding snails (CS snails) with that found in snails without emission (NCS snails). Free rediae and cercariae were thus counted in snails from both categories after their dissection at regular intervals (at $24^{\circ} \mathrm{C}$ ). In the four groups, the numbers of free rediae and free cercariae found at day 75 post-exposure ( $F$. hepatica) or at day 85 (P. daubneyil were significantly greater in CS snails than in NCS ones. The number of cercariae in NCS subgroups did not show any significant variation from day 45 p.e. to day 75 (F. hepatica, the two groups) or from day 55 to day 85 (P. daubneyi, singlemiracidium infections), while it significantly decreased with increasing time of infection in the double-miracidium infections with P. daubneyi. In NCS snails, the presence of too numerous free cercariae within the snail's body (the volume of the body allows development only of a given number of rediae) might rapidly block out redial development and intraredial differentiation of other cercariae. The numerical diminution of $P$. daubneyi cercariae in the NCS snails (double-miracidium group) might probably be due to the lysis of new cercariae just formed, probably in reason of a lack of nutrients available for these larvae within the snail.

KEY WORDS : Fasciola hepatica, Galba truncatula, Paramphistomum daubneyi, cercaria, redia.
Résumé : LA PRODUCTION RÉDIENNE ET CERCARIENNE D'Un DigÈNE CHEZ LE MOLLUSQUE HÔTE EST PLUS FAIBLE LORSQU'AUCUNE ÉMISSION CERCARIENNE N'A LIEU

Des expositions individuelles mono- et bimiracidiennes de Galba truncatula avec Fasciola hepatica (deux groupes) ou avec Paramphistomum daubneyi (deux groupes) ont été réalisées dans les conditions du laboratoire afin de comparer la production parasitaire chez des limnées qui émettent des cercaires (mollusques EC) par rapport à celle trouvée chez des individus parasités mais sans émission (limnées NEC). Les limnées vivantes et les cercaires indépendantes ont été comptées chez les mollusques des deux catégories après leur dissection à intervalles réguliers (à $24^{\circ} \mathrm{C}$ ). Dans les quatre groupes, les nombres de rédies et de cercaires indépendantes notés au 75 ème jour postexposition (F. hepatica) ou au $85^{\text {ème }}$ jour (P. daubneyi) sont significativement plus élevés chez les mollusques EC que chez les NEC. Chez ces derniers, le nombre de cercaires ne présente pas

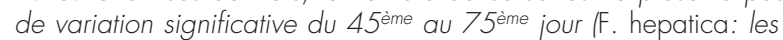

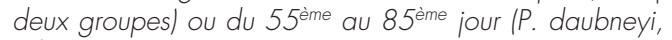
infestations individuelles à un seul miracidium) alors qu'il décroît de manière significative lorsque la durée de l'infestation augmente (P. daubneyi, infestations à deux miracidiums). Chez les limnées NEC, la présence de cercaires indépendantes trop nombreuses dans le corps du mollusque (celui-ci ne permet le développement que d'un nombre donné de rédies) bloquerait rapidement le développement des rédies et la différenciation intra-rédienne des autres cercaires. La diminution numérique des cercaires de P. daubneyi chez les mollusques NEC (groupe à deux miracidiums) pourrait être due à la lyse des nouvelles cercaires juste formées, probablement en raison d'un manque d'aliments disponibles pour celles-ci dans le corps du mollusque.

MOTS CLÉS : Fasciola hepatica, Galba truncatula, Paramphistomum daubneyi, cercaire, rédie.

ding to Dreyfuss \& Rondelaud (1995), the mean number of $F$. hepatica cercariae in NCS Lymnaea tomentosa was 293.1 from day 89 post-exposure (p.e.) to day 97 at $20^{\circ} \mathrm{C}$, whereas it was a mean of 355.8 in snails which shed their cercariae during the same period. As this finding was also noted in G. truncatula infected with Fasciola gigantica (Dreyfuss \& Rondelaud, 1995) or with Paramphistomum daubneyi (Rondelaud, unpublished results), one may wonder if the reduction in cercarial productivity is due to a diminution of redial production within the snail, or to a non-differentiation of intraredial germinal masses up to the cercaria stage. To answer this question, experimental infections of

$G$. truncatula with $F$. hepatica were carried out in the
* UPRES EA no. 3174, Faculties of Pharmacy and Medicine, 87025 Limoges, France.

Correspondence: Gilles Dreyfuss. Tel./Fax: 33-555-435863.

E-mail: gilles.dreyfuss@unilim.fr 
lab to count redial burdens and analyze their content in NSC snails as well as in those which shed their cercariae. To determine if the results obtained may be generalized to other digenean species which have a redia stage in their life-cycle, the same experiment was also made with $P$. daubneyi. Indeed, numerous snails experimentally infected with this digenean did not shed their cercariae (Abrous et al., 1999).

\section{MATERIALS AND METHODS}

T The population of G. truncatula used in this experiment came from the department of Indre (central France) and was living in a road ditch at Chézeau-Chrétien, commune of Migné. As this site was located on a calcareous soil, the shell height of adults ranged from 11 to $12 \mathrm{~mm}$. This population was known to be devoid of natural digenean infections in reason of the absence of larval forms in adult G. truncatula collected in October-November 2007 and dissected under a stereomicroscope. Seven hundred snails measuring $4 \mathrm{~mm}$ in height were collected from this site between November 2007 and February 2008. The eggs of F. hepatica were collected from the gall bladders of heavily infected cattle at the slaughterhouse of Limoges, department of Haute Vienne. To obtain eggs of P. daubneyi, adult worms were collected from the paunch of the same cattle and placed in a saline solution $(\mathrm{NaCl} 0.9 \%$, glucose $0.45 \%$ ) for $4 \mathrm{~h}$ at $37^{\circ} \mathrm{C}$. All these eggs were washed several times with spring water and were incubated at $20^{\circ} \mathrm{C}$ for 20 days in the dark (Ollerenshaw, 1971).

Table I gives the number of snail groups for every parasite, the protocol of snail infections, and the number of snails in each group at the beginning of the experiment. Snails from two groups were subjected to routine bimiracidial exposures with $F$. hepatica or with $P$. daubneyi, whereas the G. truncatula from the other two groups were submitted to single-miracidium infections. In the two groups with $P$. daubneyi, the number of snails at exposure was lower, as infected snails without shedding were more numerous for this digenean than for $F$. hepatica. After exposure, snails were subsequently reared for 30 days in 14-cm Petri dishes according to the method described by Rondelaud et al. (2007). These dishes were placed in an air-conditioned room $\left(24 \pm 1{ }^{\circ} \mathrm{C}\right)$ with a diurnal photoperiod of 12 hours and a 3,000-4,000 lx light intensity. At day 30 post-exposure, surviving snails were individually placed in 35-mm diameter Petri dishes with the same breeding conditions. Water and lettuce if necessary are changed every day. If metacercariae are present, they are counted and removed from dishes.

As the first cercarial shedding of $F$. hepatica occurred earlier than that of $P$. daubneyi (a mean of 33 days at $24^{\circ} \mathrm{C}$ instead of 51 days: unpublished result), sacrifices of $G$. truncatula were performed at day $45,55,65$, and 75 post-exposure in the case of $F$. hepatica, and at day $55,65,75$, and 85 p.e. for the other species. For every date, a sample of 10-15 CS snails (they have shed some cercariae before the date of sacrifice) and another sample of 10-15 NCS lymnaeids were collected from every group. Every snail was dissected under a stereomicroscope and counts were made on free rediae and free cercariae (of white colour for $F$. hepatica, and of brown-blackish colour for $P$. daubneyi) present within the snail's body. Intraredial cercariae were not counted. In the CS group, cercariae which have shed before the dissection of every G. truncatula were also taken into account and their number was added to the quantity of cercariae counted when this snail was dissected. The first three parameters were snail survival at day 30 p.e. (calculated in relation to the number of G. truncatula at miracidial exposure), the prevalence of infection with $F$. hepatica or with $P$. daubney $i$ in every snail group (calculated in relation with the total number of snails dissected in every group), and the shell height of infected snails at day 75 p.e. A $\chi^{2}$ test (snail survival, and prevalence) and a one-way analysis of variance (shell height) were used to establish levels of significance (Stat-Itcf, 1988). The last two parameters were the number of free rediae and that of free cercariae. Individual values recorded for every parameter and every date of sacrifice were averaged and standard deviations were calculated, taking into account snail subgroup (CS, or NCS snails). A one-way analysis of variance (Stat-Itcf, 1988) was used to establish levels of significance for $i$ ) the numbers of rediae and cercariae

\begin{tabular}{|c|c|c|c|c|c|}
\hline $\begin{array}{c}\text { Parasite } \\
\text { and snail group }\end{array}$ & $\begin{array}{c}\text { Number } \\
\text { of snails } \\
\text { at exposure }\end{array}$ & $\begin{array}{l}\text { Survival (\%) } \\
\text { at day } 30 \text { p.e. }\end{array}$ & $\begin{array}{l}\text { Number } \\
\text { of snails } \\
\text { dissected }\end{array}$ & $\begin{array}{c}\text { Prevalence }(\%) \\
\text { of infection }\end{array}$ & $\begin{array}{l}\text { Shell height (mm) } \\
\text { of infected snails } \\
\text { at day } 75 \text { p.e. }\end{array}$ \\
\hline \multicolumn{6}{|l|}{ F. hepatica } \\
\hline 1-miracidium & 200 & 87.0 & 151 & 81.4 & $8.6 \pm 1.1$ \\
\hline 2-miracidium & 200 & 79.0 & 131 & 95.4 & $8.5 \pm 1.2$ \\
\hline \multicolumn{6}{|l|}{ P. daubneyi } \\
\hline 1-miracidium & 150 & 85.3 & 128 & 85.1 & $8.8 \pm 1.4$ \\
\hline 2-miracidium & 150 & 74.0 & 111 & 100 & $8.8 \pm 1.5$ \\
\hline
\end{tabular}

Table I. - Principal characteristics of the G. truncatula groups used in this experiment. 
found in CS and NCS subgroups at day 75 p.e. (F. hepatica) or at day 85 ( $P$. daubneyi), and $i$ ) the values recorded for the four dates of sacrifice in NCS snails.

\section{RESULTS}

nail survival at day 30 p.e. (Table I) was significantly Som greater (F. hepatica: $\chi^{2}=4.53, \mathrm{P}<0.05 ; P$. daubneyi: $\left.\chi^{2}=5.94, \mathrm{P}<0.05\right)$ in single-miracidium infections than in double-miracidium groups. The prevalence of $P$. daubneyi infection was significantly higher $\left(\chi^{2}=\right.$ 18.89, $\mathrm{P}<0.001)$ in double-miracidium infections while no significant difference between the rates of $F$. hepatica was found. The shell height of infected snails at day 75 p.e. was the same in the four groups. No significant difference between the shell heights of CS snails and those of NCS ones was noted, whatever snail group.

\section{SNAILS INFECTED WITH $F$. HEPATICA}

In single-miracidium infections, the number of live rediae at day 75 p.e. (Fig. 1a) was significantly higher $(\mathrm{F}=9.89, \mathrm{P}<0.01)$ in CS snails than in NCS ones. A

Single-miracidium infections

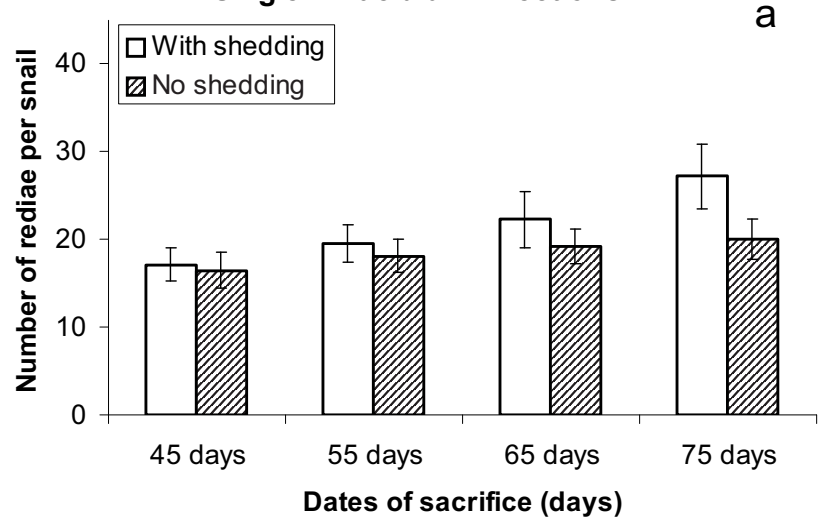

C

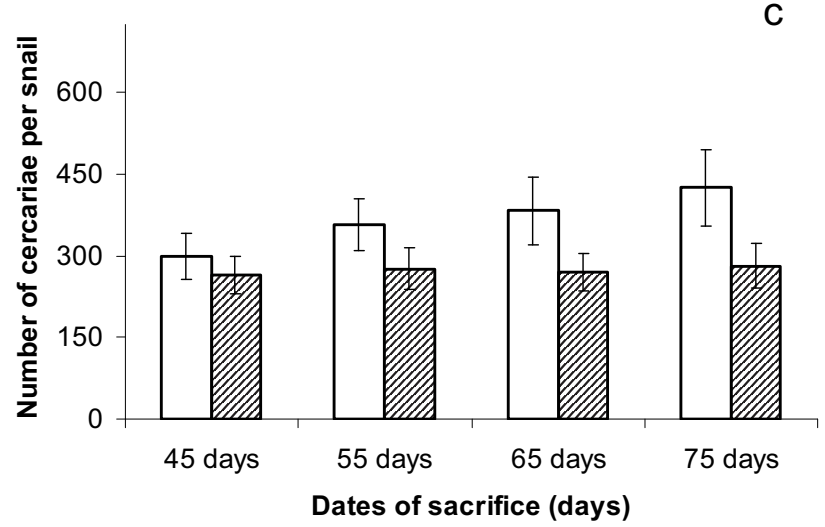

similar finding was found in the double-miracidium group (Fig. 1b), with a significantly greater burden at day $75(\mathrm{~F}=18.47, \mathrm{P}<0.001)$ in CS snails. In both NCS subgroups, the number of rediae did not show any significant variation from day 45 to day 75 .

As for rediae, the quantity of cercariae counted at day 75 in the single-miracidium group (Fig. 1c) was also significantly higher $(\mathrm{F}=13.16, \mathrm{P}<0.001)$ in $\mathrm{CS}$ snails than in NCS ones. In the double-miracidium group (Fig. 1d), the same difference between cercarial numbers at day 75 was also significant $(\mathrm{F}=14.32$, $\mathrm{P}<0.01$ ). No significant difference between the numbers found for the four dates of sacrifice was noted in NCS snails, whatever snail group.

Contrary to CS snails which contained numerous empty rediae at day 75 , these larvae were few in numbers in all NCS snails. Some internal metacercariae (VareilleMorel et al., 1993) were noted in both NCS subgroups from day 65 (data not shown).

\section{SNAILS INFECTED WITH $P$. DAUBNEYI}

Figure 2 gives the numbers of rediae and cercariae found in the two groups of snails from day 55 to day
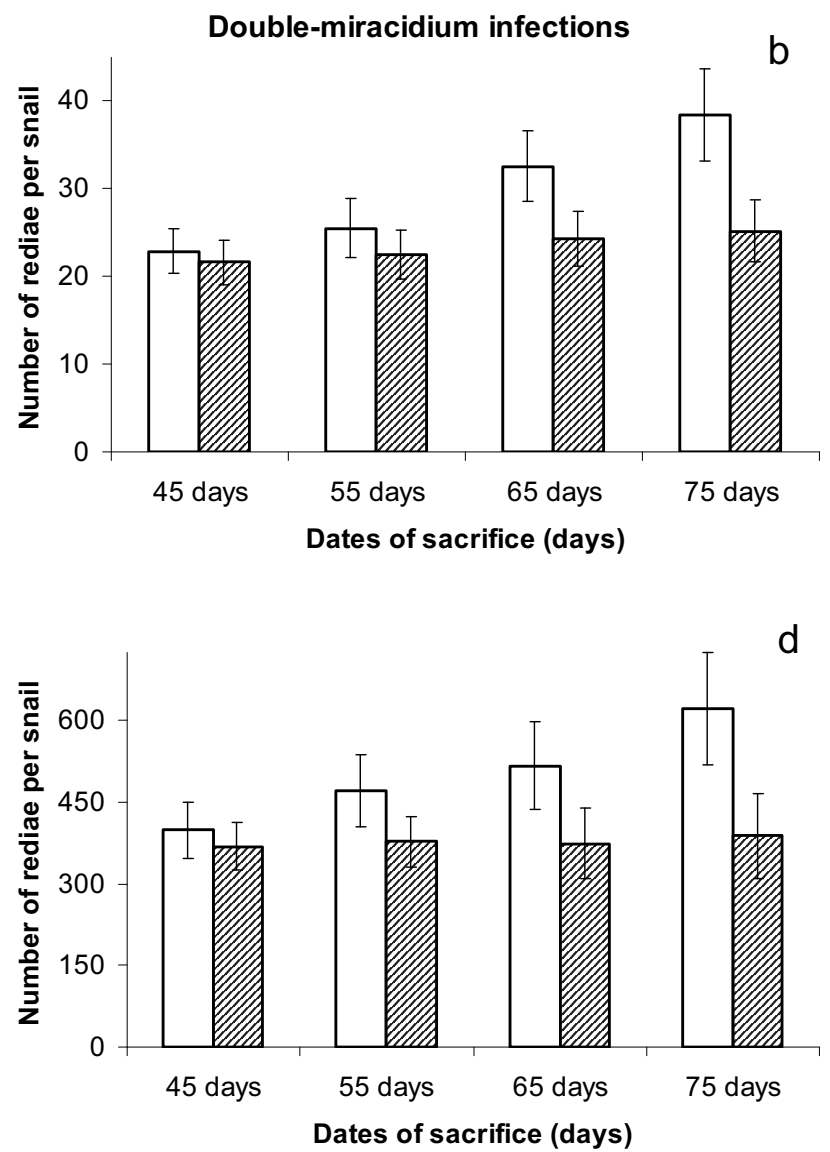

Fig. 1. - Mean values and S.D. for the number of $F$. hepatica rediae (a, b) and that of cercariae (c, d) in single-miracidium infections of G. truncatula (a, c) and in double-miracidium ones (b, d) in relation to the length of experiment and the existence or the absence of cercarial shedding before each date of snail sacrifice. 
Single-miracidium infections

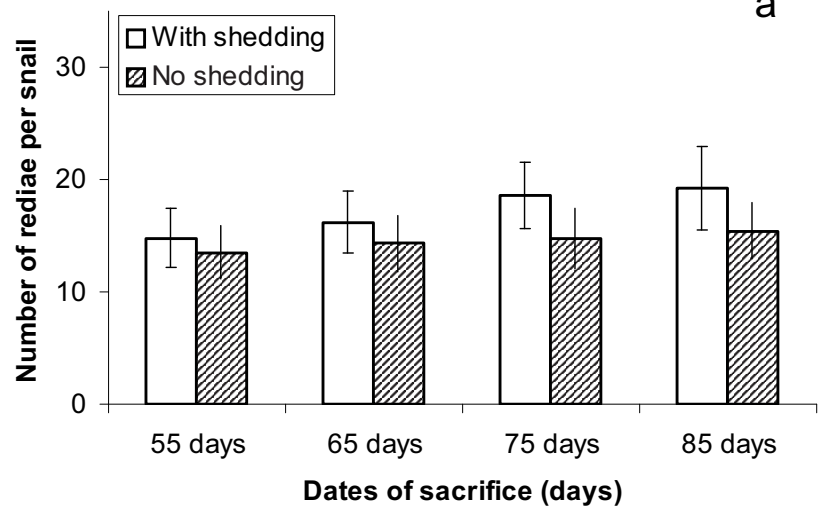

C

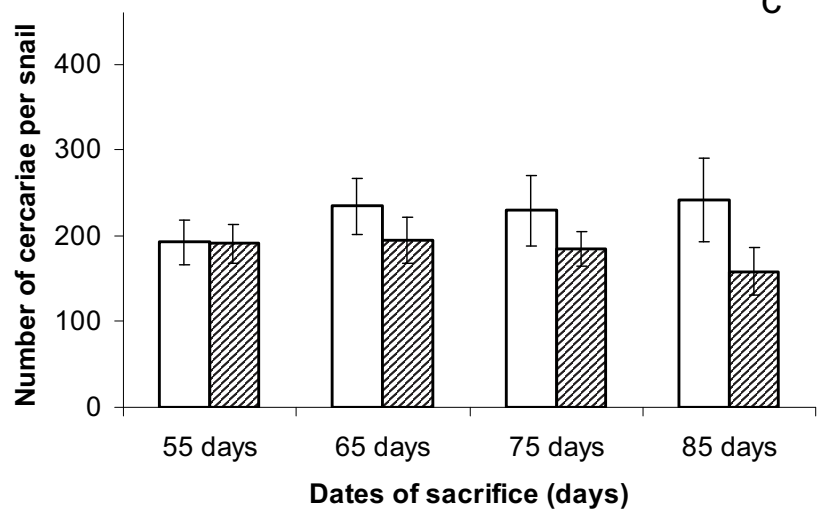

Double-miracidium infections
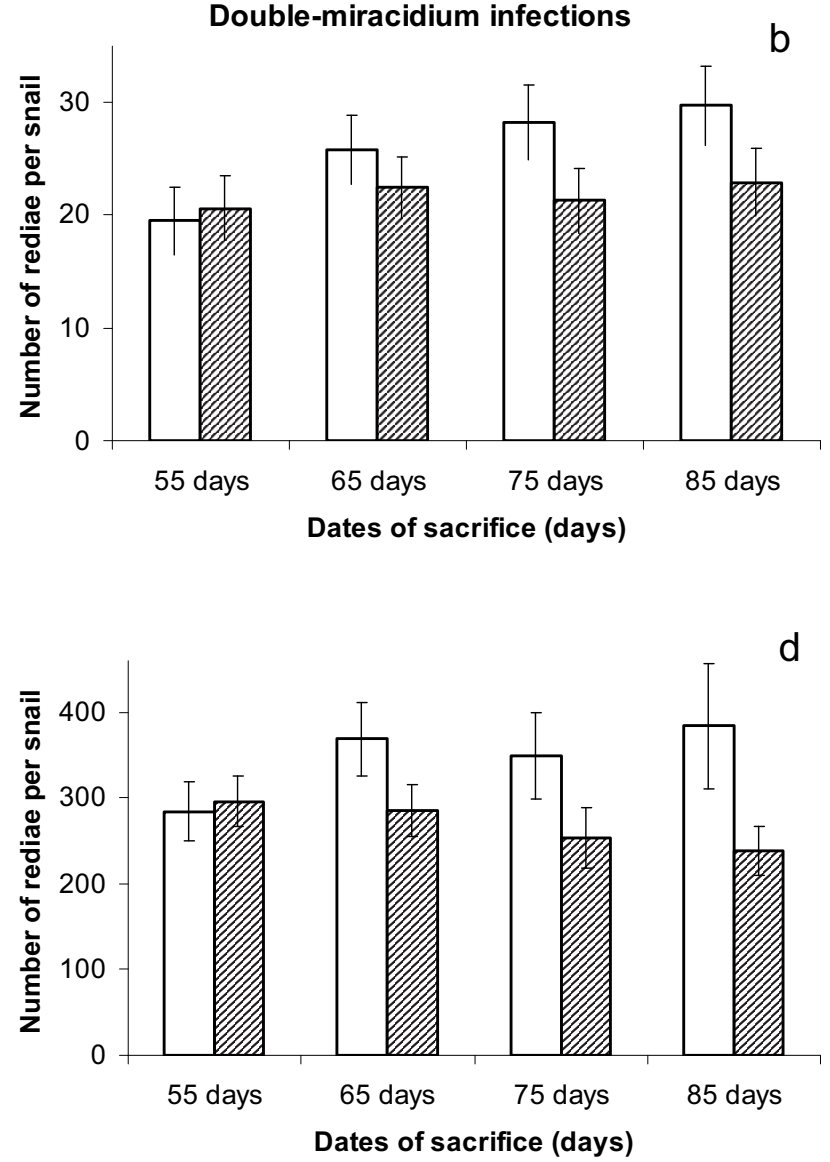

Fig. 2. - Mean values and S.D. for the number of $P$. daubneyi rediae (a, b) and that of cercariae (c, d) in single-miracidium infections of G. truncatula (a, c) and in double-miracidium ones (b, d) in relation to the length of experiment and the existence or the absence of cercarial shedding before each date of snail sacrifice.

85 p.e. Compared to CS snails, the number of free rediae found in NCS molluscs (Fig. 2a, b) was significantly lower in the single-miracidium $(\mathrm{F}=4.31, \mathrm{P}<0.05)$ and double-miracidium $(\mathrm{F}=8.04, \mathrm{P}<0.01)$ groups. In both NCS subgroups, insignificant differences between the numbers of free rediae recorded for the four dates of sacrifice were noted.

Significant differences between the numbers of cercariae found at day 85 p.e. (Fig. 2c, d) were recorded, with higher values in CS snails (single-miracidium group: $\mathrm{F}=8.84, \mathrm{P}<0.01$; double-miracidium group: $\mathrm{F}=8.04$, $\mathrm{P}<0.01)$. In spite of the slight decrease of mean cercarial numbers in NCS snails from day 65 (Fig. 2c), no significant variation was noted in the single-miracidium group, whereas a significant decrease $(\mathrm{F}=2.76, \mathrm{P}<$ 0.05 ) from day 55 to day 85 was found in the doublemiracidium group.

In both NCS subgroups, empty and free rediae were few in numbers at day 85 p.e. while they were numerous in all CS snails at the same date. Several internal cysts were also observed in NCS snails from day 75 p.e. (data not shown).

\section{DISCUSSION}

T $\mathrm{n}$ CS snails, the number of free rediae and that of free cercariae were significantly greater at day 75 p.e. (F. hepatica) or at day 85 ( $P$. daubneyi) at $24^{\circ} \mathrm{C}$ than those counted in NCS lymnaeids. According to these results, there was a limitation in the numbers of rediae and cercariae produced within the snail if no shedding occurs. The most likely explanation is to relate this finding in NCS snails to the volume of the snail's body because this one allows development only of a given number of rediae, as demonstrated by Rondelaud \& Barthe (1987) for F. hepatica rediae in G. truncatula. If no cercarial shedding occurs (the first shedding of $F$. hepatica cercariae, for example, began at day 33 p.e. at $24^{\circ} \mathrm{C}$ ), the presence of too numerous free cercariae within the body of these NCS snails would quickly block out redial development and intraredial differentiation of other cercariae. Indeed, there was no significant variation of free cercariae in these NCS snails after day 45 p.e. in the case of $F$. hepatica, while free cercariae of $P$. daubneyi decreased in num- 
bers after day 55, at least in the double-miracidium group. However, another hypothesis based on the existence of a genetic polymorphism of cercariae in the case of NCS snails cannot be excluded.

Compared to $F$. hepatica, there was a numerical reduction of $P$. daubneyi over time in the NCS snails from the double-miracidium group and this finding is a new element in our knowledge on the life-cycle of $P$. daubneyi. This last result is more difficult to interpret for the following reasons. First, even if several internal cysts were found in these snails from day 75 p.e., no aggregate of degenerating cercariae was seen in these G. truncatula for the oldest larvae and all of them were still able of swim in snails sacrificed at days 75 and 85. Secondly, the decrease of cercarial burden cannot be explained by the progressive numerical diminution of white procercariae (Abrous et al., 1999) over time because it was only noted for cercariae after acquisition of their brown-blackish colour. In our opinion, this reduction would affect new cercariae just formed and would probably be due to a lack of nutrients available for these larvae within the snail. Compared to $F$. hepatica, lower numbers of rediae and of cercariae were noted in snails infected with $P$. daubney $i$ and this finding must be related to the peculiarities of the life cycle for every digenean. Indeed, at least three redial generations developed one another within the snail in the case of $F$. hepatica (Rondelaud \& Barthe, 1987) whereas there were two generations of rediae only in the case of P. daubneyi (Sey, 1979; Abrous et al., 1997). Moreover, the larval development of $F$. hepatica is quicker than that of $P$. daubneyi, as shown in Figures 1 and 2. As a consequence, the redial burden developing in a snail of given height and the number of cercariae produced by these larvae were lower in the case of $P$. daubneyi than for $F$. bepatica. This consequence was also found in the case of NCS snails.

\section{REFERENCES}

Abrous M., Rondelaud D. \& Dreyfuss G. Paramphistomum daubneyi: the development of redial generations in the snail Lymnaea truncatula. Parasitology Research, 1997, 83, 64-69.

Abrous M., Rondelaud D. \& Dreyfuss G. Influence of low temperatures on the cercarial shedding of Paramphistomum daubneyi from the snail Lymnaea truncatula. Parasite, 1999, 6, 85-88.

Dreyfuss G. \& Rondelaud D. Comparative studies on the productivity of Fasciola gigantica and F. hepatica sporocysts in Lymnaea tomentosa died after a cercarial shedding or without emission. Parasitology Research, 1995, 81, 531-536.

OllerEnshaw C.B. Some observations on the epidemiology of fascioliasis in relation to the timing of molluscicide applications in the control of the disease. Veterinary Record, 1971, 88, 152-164.
Rondelaud D. \& Barthe D. Fasciola hepatica L. : étude de la productivité d'un sporocyste en fonction de la taille de Lymnaea truncatula. Parasitology Research, 1987, 74, 155160.

Rondelaud D., Fousi M., Vignoles P., Moncef M. \& Dreyfuss G. Optimization of metacercarial production for three digenean species by the use of Petri dishes for raising lettucefed Galba truncatula. Parasitology Research, 2007, 100, 861-865.

SEY O. Life-cycle and geographical distribution of Paramphistomum daubneyi Dinnik, 1962 (Trematoda: Paramphistomata). Acta Veterinaria Academiae Scientiarum Hungaricae, 1979, 27, 115-130.

STAT-ITCF. Manuel d'utilisation. Institut Technique des Céréales et des Fourrages, Service des Études Statistiques, BoigneVille, 1988, 210 p.

Vareille-Morel C., Esclaire F., Hourdin P. \& Rondelaud D. Internal metacercarial cysts of Fasciola hepatica in the pulmonate snail, Lymnaea truncatula. Parasitology Research, 1993, 79, 259-260.

Vignoles P., Dreyfuss G. \& Rondelaud D. Larval development of Fasciola hepatica in experimental infections: variations with populations of Lymnaea truncatula. Journal of Helminthology, 2002, 76, 179-183.

Reçu le 31 janvier 2009 Accepté le 10 septembre 2009 